УДК 159.9.07

doi: $10.15330 / p s .10 .1 .123-132$

\title{
Тетяна Здоровець
}

Ніжинський державний університет імені Миколи Гоголя

tzdorovets@ukr.net

\section{НАРАТИВНА КОМПЕТЕНТНІСТЬ ЯК СКЛАДНИК ПРОФЕСІЙНОЇ КОМПЕТЕНТНОСТІ МАЙБУТНІХ ПРАКТИЧНИХ ПСИХОЛОГІВ}

У статті проаналізовано проблему наративної компетентності практичного психолога як основний складник його професійної компетентності. Показано, щзо професійна компетентність психолога є складним психологічним утворенням, яке забезпечує успішність його професійної діяльності та включає в себе систему діяльнісно-рольових (знання, уміння $і$ навички) та особистісних (професійно важливих якостей) характеристик, важливе місие серед яких займає наративна компетентність. Наративна компетентність передбачає сформованість в особистості наративу як структурної рамки та наявність «набору» базових наративів, щуо мають соиіокультурну природу, вмінь розгортати наративні структури у зв'язну розповідь або історію. Націленість психологічної допомоги на роботу із запитами клієнтів, шзо будуються на наративі як історії життя людини, яка звернулася за допомогою, робить надзвичайно важливим вивчення наративної компетентності, щуо реалізується в процесах розуміння та самопізнання, осмислення та переосмислення активним суб'єктом інформаиії про навколишній світ $i$ себе в ньому. Виявлено, щзо наративна компетентність є складником професійної компетентності практичного психолога $і$ засобом усвідомлення ним власного досвіду та власної особистості, щзо виражається у вмінні побачити за історією особистості у ході надання психологічної допомоги ї̈ індивідуальний наратив. Зроблено висновок про те, щзо несуперечлива Я-концепція, рефлексивність, діалогічна спрямованість у спілкуванні, керування почуттями й емоціями інших (складові частини емоційного інтелекту), чутливістьраціональність (складники комунікатинної компетентності) $\epsilon$ комплементарними до особистості практичного психолога якостями, наявність яких обумовить забезпечення особистісного зростання клієнта в прочесі індивідуальної і групової роботи.

Ключові слова: наративна компетентність, наратив, сочіальний інтелект, емочійний інтелект, діалогізм, комунікативна компетентність, рефлексія, несуперечлива Я-концепція.

Постановка проблеми Соціальний запит ставить високі вимоги до професійної підготовки психолога та визначає професійну компетентність майбутнього фахівця як одну з актуальних проблем сучасної психологічної освіти. У сучасній науково-психологічній літературі визначається безліч понять, які характеризують особливості розвитку і професійного становлення особистості фахівця, здатного до ефективного виконання професійної діяльності, серед яких провідне місце належить таким поняттям, як «професійна компетентність», «професійна майстерність» і «професіоналізм». Зазначені поняття показують не тільки генезис особистості фахівця в процесі його професіоналізації, а й характеризують сутність рівнів реалізації професійної діяльності. Актуальність дослідження проблеми формування наративної компетентності як основного складника професійної компетентності у майбутніх практичних психологів протягом їх навчання та становлення основ професіоналізму суттєво зростає у зв'язку з перебудовою системи освіти в сучасній Україні. Наративна компетентність практичного психолога передбачає, по-перше, володіння всіма елементами наративної структури, тобто сформованість в особистості наративу як структурного утворення, фрейма, а також наявність «набору» базових соціокультурних наративів, або метанаративів, вміння розгортати наративні структури у зв'язну розповідь або історію, яка великою мірою базується на культурно зумовлених метанаративах. По-друге, наративна компетентність передбачає вміння побачити за оповіддю, історією іншого (клієнта) у ході надання психологічної допомоги його індивідуальний наратив, тобто наративну, а потім і особистісну ідентичність.

Мета статті полягає у розгляді наративної компетентності як необхідного складника професійної компетентності майбутніх практичних психологів. 
Основний матеріал і результати дослідження. Поняття «професійна компетентність» увійшло в науковий обіг у 80-ті роки минулого століття з праць Ю. К. Бабанського, С. П. Баранова, В. О. Сластьоніна і розглядалось як складова частина професіоналізму. Але насьогодні, за наслідками аналізу наукової літератури, немає в науці єдиного підходу до визначення поняття професійної компетентності.

Згідно $з$ системним підходом (Т. Т. Браже, Н І. Запрудський) професійна компетентність трактується як певна система, що інтегрує знання, уміння, навички, професійно значущі якості особистості і забезпечує виконання особистих професійних зобов 'язань [3].

Відповідно до концепції «інтегрованого розвитку компетентності» В. Чапанат, Г. Вайлер, Я. Лефстед, професійна компетентності спеціаліста - це інтеграція інтелектуальних, моральних, соціальних, естетичних, політичних аспектів знань і вмінь, тобто інтеграція знань та вмінь з різних сфер життєдіяльності людини, що необхідні для формування умінь виконання діяльності творчого рівня [3].

В. В. Крижко та С. М. Павлютенков пропонують розглядати професійну компетентність через призму трьох сфер, кожна $з$ яких має певні рівні професійної майстерності. Перша - операційно-технологічна: знання, уміння і навички, професійно важливі якості. Друга - мотиваційна сфера: духовний світ особистості - потреби, професійні орієнтації та мотиви діяльності. Третя сфера - рефлексивна, яка відтворює уявлення про себе, власні якості й результати діяльності, самооцінку, що формує навички самоаналізу власної діяльності [4].

Професійна компетентність, на думку А. К. Маркової, має чотири блоки: а) професійні (об'єктивно необхідні) знання; б) професійні (об'єктивно необхідні) уміння; в) професійні психологічні позиції, установки, необхідні для професії; г) особистісні особливості, що забезпечують оволодіння професійними знаннями й уміннями [9]. У наступних роботах авторки особистість як структурний компонент професійної компетентності набуває більшого значення, відтак А. К. Маркова вже виділяє спеціальну, соціальну, особистісну та індивідуальну види компетентностей [9].

Згідно з І. Б. Міщенко найчастіше у структурі компетентності виділяють: операційно-технічну сферу (знання, навички, уміння, професійно значущі якості); мотиваційну сферу (спрямованість, інтереси, мотиви, потреби); практично-діяльнісну сферу (засоби виконання діяльності, результативні показники діяльності). Наповнення змістом структурних компонентів відбувається варіативно, залежно від виду діяльності. Дослідниця зазначає, що, крім названих структурних компонентів, у деяких дослідженнях виділяють рефлексивну сферу (аналіз та оцінку відповідності здобутого результату поставленим цілям) [12].

Відповідно до уявлень О. Ф. Брискіної структура професійної компетентності розкривається через уміння, а саме: аналітичні, гностичні, мобілізаційні, інформаційні, орієнтаційні та комунікативні [8].

С. Г. Молчанов у понятті «професійна компетентність» виділяє такі складники: професійна кваліфікація; соціально-професійний статус; професійно значущі особистісні якості. Автор зазначає, що у професійній компетентності варто фіксувати іiі соціальний аспект, що відображає особливості професії як представника групи професій соціальної сфери [8].

Польський науковець Р. Квасніца вважає, що структура професійної компетентності складається 3 двох комплексів-підструктур: комплекс практично-моральних знань, досвіду та вмінь (аксіологічні знання, досвід та вміння, необхідні для розуміння світу, оточення, себе, що забезпечує порозуміння шляхом діалогу та взаємодії. Він може бути диференційованим на комунікативні, інтерпретаційні та моральні компетентності) та комплекс технологічно-аналітичних умінь та навичок (вміння аналізувати, порівнювати, транслювати, трансформувати, досягаючи бажаної мети. Має такі групи компетентностей: постуляційні, методичні і реалізаційні) [2].

Наукові джерела не однозначно трактують і поняття «компетентність»: 
1) «компетентність» (від лат. compeience) - поняття, що висвітлює аспекти поведінки людини, пов'язані з виконанням роботи, визначає основну характеристику особистості, яка досягла або здатна досягти високих результатів у діяльності;

2) «компетентність» (лат. competens - відповідний, здібний) означає коло повноважжень будь-якої посадової особи чи органу; володіння знаннями, досвідом у певній галузі. Під компетентністю ми розуміємо сукупність взаємозалежних якостей особистості (знання, уміння, навички, способи діяльності), необхідних для якісної продуктивної діяльності.

П. Горкуненко характеризує компетентність як достатній рівень професійних знань, умінь і навичок та сукупності особистісних можливостей і досвіду фахівця [3]. У широкому сенсі компетентність в основному розуміється як ступінь соціальної та психологічної зрілості людини, яка передбачає певний рівень психічного розвитку особистості, психологічну готовність до певного виду діяльності, що дає індивіду змогу успішно функціонувати в суспільстві й інтегруватися в нього. У вузькому сенсі компетентність розглядається як діяльнісна характеристика, міра інтегрованості людини в діяльність. А це передбачає певну світоглядну спрямованість особистості, ціннісне ставлення до діяльності. Деякі дослідники вважають, що суттєвим моментом компетентності $є$ здатність ухвалювати відповідні рішення в процесі вирішення конкретних проблем і виробничих завдань [15].

Проблема узгодження вітчизняної термінології та науки загалом із компетентнісним підходом полягає в тому, що науковці переважно користуються традиційною і зрозумілою тріадою «знання-уміння-навички», з якої виходить ціла низка категорій та понять. Проте поняття «компетентність» є ширшим, ніж знання чи вміння, і передбачає здатність фахівця використовувати в конкретній ситуації набуті знання, уміння, навчальний та життєвий досвід, знання ним методів пошуку необхідної інформації, уміння ï аналізувати, бачити проблеми і шляхи їх вирішення, самоефективність, а також розуміння необхідності навчатися впродовж усього життя [6].

Аналіз сучасної літератури 3 проблеми досліджуваних категорій засвідчив, що «компетентність» $є$ більш широким поняттям, яке характеризує й визначає рівень професіоналізму особистості, а іiі досягнення відбувається через здобуття особистістю необхідних компетенцій, що становлять мету професійної підготовки фахівця [6]. Так, В. Г. Первутинський вважає, що компетентність передбачає володіння людиною відповідною компетенцією, яка містить ії особистісне ставлення до предмета діяльності. Компетентна в окремій галузі людина має певні знання та здібності, що надають їй можливість обгрунтовано судити про цю галузь й ефективно діяти в ній. У межах цього підходу поєднуються, зокрема, поняття «компетентність» і «готовність», які визначаються не як тотожні, а як зв'язок між внутрішнім потенціалом та реальним його втіленням (внутрішньою сутністю і зовнішнім виявом).

Отже, професійна компетентність може розумітися як один із структурних компонентів професійної готовності до конкретного виду діяльності [15]. Розгляд сутності поняття «професійна компетентність» передбачає також виявлення відмінностей чи тотожності між поняттями «професійна компетентність» та «професіоналізм». На основі аналізу психолого-педагогічної літератури нами виокремлено деякі означення, що, як видається, найбільш повно характеризують поняття професіоналізму:

- міра і ступінь досконалості, якої досягає людина в процесі своєї діяльності, коли підіймається на вищу сходинку майстерності, стає авторитетом, майстром у своєму роді заняття [1];

- інтегральна характеристика людини, що передбачає наявність високого рівня здійснення нею професійної діяльності та життєву зрілість ії особистості [4].

Комплементарними до особистості практичного психолога якостями, наявність яких обумовлює забезпечення особистісного зростання клієнта в процесі індивідуальної і 
групової роботи, є соціальний інтелект, емоційний інтелект, діалогізм, комунікативна компетентність, рефлексія, несуперечлива Я-концепція.

Для перевірки даного твердження доцільно використати наступні методи: методику діагностики соціального інтелекту Н. Ф. Каліної [7], методику діагностики емоційного інтелекту М. А. Манайлової [11], методику діагностики інтерактивної спрямованості особистості Н. Є. Щукова у модифікації М. П. Фетіскіна [17], методику діагностики спрямованості особистісного спілкування С. Л. Братченка [5], методику діагностики комунікативної соціальної компетентності М. П. Фєтіскіна, В. В. Козлова, Г. М. Мануйлова [17], психометричну методику діагностики індивідуальної міри розвитку індивідуальної рефлексивності А. В. Карпова [10], методику визначення ясності Я-концепції І. Я. Шелянюк [18].

У дослідженні брали участь студенти I (42 особи) та IV (46 осіб) курсів Ніжинського державного університету імені Миколи Гоголя, що навчаються за спеціальністю «психологія» та «практична психологія» на денній формі навчання.

Застосування методики діагностики соціального інтелекту Н. Ф. Каліної сприятиме визначенню рівня розвитку соціального інтелекту як когнітивної основи комунікативної компетентності майбутніх фахівців у галузі практичної психології.

Когнітивною основою комунікативної компетентності особистості Н. Ф. Каліна називає соціальний інтелект, який виступає специфічним когнітивним утворенням, що забезпечує ефективність соціальної активності особистості. Серед конструктів, що втілюють функціональну структуру соціального інтелекту, - уміння шукати необхідну інформацію, відсутність імпліцитних уявлень, рефлексія на кінцеву мету, інтерес до людей, розуміння достатності результату в груповій діяльності, здатність до асиміляції нетрадиційного досвіду.

В ході кількісного аналізу методики діагностики соціального інтелекту Н. Ф. Каліної виявлено, що студенти I курсу мають низький рівень розвитку соціального інтелекту (70\%) як когнітивної основи комунікативної компетентності. 20\% мають показники середнього рівня та $10 \%$ - високого, а у п'ятикурсників діагностовано $37,5 \%$ - середній рівень, 22,5\% - високий, 40\% - низький рівень розвитку.

Емоційний інтелект є здатністю людини усвідомлювати, приймати та регулювати емоційні стани та почуття інших людей та себе. В структурі емоційного інтелекту є два аспекти: внутрішньоособистісний і міжособистісний, тобто здатність управляти собою та стосунками з іншими людьми.

В ході надання психологічної допомоги емоційний інтелект здійснює регуляцію внутрішньої та зовнішньої діяльності фахівця, забезпечує здатність емоційного розуміння та пізнання власного стану та психологічного стану партнера по спілкуванню (клієнта); управління власними діями відповідно до свідомо поставленої мети, регулюючи внутрішні стани (бажання та потреби); надання значущості явищам та ситуаціям, що визначають переживання партнерів по спілкуванню.

Конструктами емоційного інтелекту, на думку М. А. Манайлової, є усвідомлення власних почуттів та емоцій, керування власними почуттями та емоціями, усвідомлення почуттів та емоцій інших людей, керування почуттями та емоціями інших людей.

Діалогічність як суттєва ознака інституту психологічної допомоги - невід'ємна риса професіоналізму взаємодії психолога з психологічною реальністю клієнта незалежно від парадигми психологічної допомоги, у якій працює фахівець. Діалогічність передбачає рівноцінну, паритетну взаємодію смислів у процесі інтерсуб'єктної інтерпретації фахівцем і клієнтом травмівних подій життя останнього, що констатують породження, синтез нового смислу психологічної ситуації і досягнення психічного гомеостазу клієнта, його особистісний ріст. Отже, діалогічність взаємодії передбачає створення єдності цілей i смислів суб'єктів, що визначає співробітництво як важливу ознаку реальної взаємодії. Методика, створена Н. Є. Щуковим та модифікована М. П. Фетіскіним, призначена для встановлення інтерактивної спрямованості особистості, де визначена спрямованість, 
орієнтована на взаємодію і співробітництво. Співробітництво як спрямованість особистості, характеризується виявленням інтересів, потреб обох сторін, обговорення їх, пошук взаємоприйнятного рішення, формуванням альтернатив у вирішенні проблеми і не може бути реалізована інакше, як на підставі актуалізації діалогічних інтенцій усіх партнерів по спілкуванню.

Методика діагностики спрямованості особистісного спілкування С. Л. Братченка орієнтована на виявлення проявів діалогічної комунікативної спрямованості. Позиція В. Н. Панфьорова $з$ приводу специфіки проявів діалогу передбачає логічне, смислове та психологічне єднання партнерів, їх включеність у співробітництво, узгодження позицій. С. Л. Братченко розглядає діалог як комунікативне співробітництво, як взаємодію різних логік, точок зору.

Отже, виявлення рівня спрямованості особистості на співробітництво за методикою діагностики інтерактивної спрямованості особистості Н. Є. Щукова (модифікація М. П. Фетіскіна) та проявів діалогічної комунікативної спрямованості за методикою діагностики спрямованості особистісного спілкування С. Л. Братченко можна розглядати як виявлення рівня діалогічної спрямованості суб'єкта (психолога) на співробітництво у взаємодії з іншими (клієнтом).

У ході дослідження встановлено, що досліджуваним властивий низький рівень розвитку інтерактивних орієнтацій.

С. Л. Братченко виділяє у спілкуванні його діалогічну та монологічну спрямованість. В свою чергу, монологічна поділяється на авторитарну, альтероцентристську, маніпулятивну, конформну та індиферентну.

М. Я. Амінов, М. В. Молоканов зазначають, що професія психолога в комунікативному плані виступає прикладом спеціальних здібностей, які вимагають інтерперсональних умінь, тобто таких якостей особистості, що забезпечують успішну взаємодію між людьми, взаєморозуміння, організацію спільної діяльності. Складниками системи інтерперсональних умінь науковці називають готовність до контактів, уміння їх підтримувати, уміння зберігати емоційну рівновагу в процесі спілкування, високу чутливість, емоційну привабливість для інших людей.

Отже, однією з найголовніших серед професійних спонук практичного психолога має бути орієнтація на людину, іiї прийняття. Тому використання методики «Діагностика комунікативної соціальної компетентності» спрямовано на отримання більш цілісного уявлення про особистість психолога-фахівця, створення імовірнісного прогнозу успішності його професійної діяльності.

В емпіричному дослідженні встановлено, що комунікативна компетентність студентів як I, так і IV курсів характеризується відкритістю, легкістю, комунікативністю, середнім рівнем розвитку логічного мислення та кмітливості, емоційною стійкістю та спокоєм, середнім рівнем безпечності, життєрадісності,веселості, середнім рівнем чутливості, незалежністю, орієнтацією на себе, середнім рівнем самоконтролю та вміння підкорятися правилам та відсутністю особистісних проблем.

У дослідженнях І. М. Семенова та С. Ю. Степанова рефлексія трактується як переосмислення і перебудова суб'єктом змісту своєї свідомості, що розгортається в 5 етапів: актуалізація смислових структур Я; вичерпання цих актуалізованих смислів при апробації стереотипів досвіду; їх дискредитація у контексті виявлених суперечностей; інновація принципів конструктивного переборення цих суперечностей; реалізація через реорганізацію змісту особистого досвіду.

Розглядаючи особливості професійної рефлексії практичного психолога, Н. І. Пов’якель відзначає іії здвоєність, дзеркальність взаємного відображення суб'єктів спілкування і взаємодії, самопізнання і пізнання, змістом яких виступає відтворення особистісних властивостей. Дослідниця підкреслює особливе значення когнітивного компонента професійної рефлексії психолога-практика, який спрямований на усвідомлення себе реального і 
себе як особистості, усвідомлення себе як професіонала, своїх дій, поведінки та прогнозування їх наслідків.

Психометрична методика діагностики індивідуальної міри розвитку індивідуальної рефлексивності А. В. Карпова має на меті вивчення рівня розвитку рефлексивності як психологічної властивості, рефлексії як процесу та рефлексивності як результату для забезпечення професійної компетентності практичного психолога.

Студентам I курсу властивий низький рівень рефлексивності $(52,5 \%)$ як інтегрованого показника, що передбачає рівень розвитку рефлексивності як психологічної властивості, рефлексії як процесу і рефлексування як результату; 45\% - середній рівень; 2,5 високий.

Студенти IV курсу мають середній рівень рефлексивності (80\%) та низький (20\%).

Р. Бернс визначив Я-концепцію як динамічну систему уявлень людини про саму себе, що включає: усвідомлення своїх фізичних, інтелектуальних та інших якостей, самооцінку, суб'єктивне сприймання зовнішніх чинників впливу на особистість. Будучи важливим регулятором поведінки, Я-концепція виконує потрійну функцію:

1) сприяє досягненню внутрішньої інтерпретації набутого досвіду;

2) визначає характер і особливості інтерпретації набутого досвіду;

3) слугує джерелом очікувань стосовно власної поведінки і самого себе.

Я-концепція створює відчуття своєї постійної визначеності, самототожності та адекватності. Тому наявність несуперечливої, позитивної Я-концепції - одна 3 найважливіших умов ефективності професійної діяльності практичного психолога, особистість якого виступає основним знаряддям, інструментом надання психологічної допомоги (Ю. Альошина, О. Бондаренко, Р. Мей та ін.)

Студентам I курсу властивий середній (70 \%) та низький (30 \%) рівні ясності Я-концепції. Студенти IV курсу мають середній рівень ясності (60\%) та високий (40\%) рівень ясності Я-концепції.

Ідея про те, що не тільки людська свідомість ототожнюється з сумою певних текстів, але й дії людини, події іiі життя є характерними для сучасного постструктуралізму, який базується на думці Ж. Дерріда про те, що нічого не може існувати поза текстом. Приймаючи дане трактування, потрапляємо в поле діяльності герменевтики, предметом якої, за Дільтеєм, є душевний досвід, який виявляється в словах. Герменевтику згідно 3 Н. В. Чепелєвою трактуємо як теорію та загальні правила інтерпретації текстів [14].

Текст у професійній діяльності психолога трактується в широкому семантичному смислі: 1) як текст, що представлений в писемному вигляді; 2) як текст, що виникає у клієнта під час психотерапії; 3) як текст, який людина творить у внутрішньому діалозі, намагаючись осмислити, усвідомити, зрозуміти себе, свій досвід та проблеми.

Отже, текст є засобом інтерпретації не тільки навколишньої дійсності, а й іншого, а також текст є могутнім засобом самопізнання. Розуміння дійсності, себе чи іншого є діалогічним, оскільки, сприймаючи повідомлення, людина будує свій «зустрічний» текст, використовуючи зразки культури (історії іншого), але доповнює власними інтерпретаціями, власним баченням ситуації.

Але мова йде не стільки про текстуалізацію свідомості, скільки про іï наративізацію, про здатність людини описати себе та свій життєвий досвід у вигляді зв'язної розповіді, вибудованої за принципами та механізмами жанрової організації художнього тексту.

Ідею про те, що людська свідомість має наративну структуру, висувають як зарубіжні, так і вітчизняні автори. Зокрема пропонується так званий «наративний принцип», в основі якого лежить положення про те, що люди мислять, роблять певні життєві вибори відповідно до наративних структур, тобто наратив розглядається як організаційний принцип діяльності особистості (Ф. Сабрін). Деякі зарубіжні автори висловлюють думку про те, що життя людини великою мірою насичене оповідями, історіями, в яких відображений весь іiі досвід, а повідомляючи історії свого життя, особистість стає відповідальною за нього (Д. Карр, К. Метінгел, М. Вайт). Така відповідальність береться за основу в 
концепції наративної ідентичності (П. Рікер). Відповідно до даної концепції особистість усвідомлює себе в процесі оповідання іншому історії свого життя $[13 ; 14 ; 16]$.

У дослідженнях вітчизняних психологів наратив розглядається як упорядкування життєвих подій в єдину послідовність, що побудована згідно із загальною життєвою концепцією оповідача (Н. В.Чепелєва). Зауважується, що текст-наратив доцільно розглядати як засіб саморозуміння («історія для себе») та засіб самоподачі, самопред’явлення («історія для іншого»). Однією 3 найважливіших його функцій є саме самопрезентація саморозкриття, декларування і ствердження індивідуальної системи цінностей, поглядів, переконань. Завдяки наративу суб'єкт усвідомлює себе, свій досвід, презентує певну точку зору, стверджує себе таким, яким він прагне бути, а також створює своє минуле. Тобто людина, проживаючи своє життя, конструює його історію. В процесі такого конструювання відбувається переосмислення власного досвіду та власної особистості, виникає нове бачення тих подій життя, власних рис та якостей, що з певних причин не усвідомлювалися чи не приймалися людиною, - а це призводить до конструювання більш цілісної історії життя.

Наративна компетентність передбачає сформованість в особистості фахівця наративу як структурної рамки, що має соціокультурну природу та виявляється у вмінні розгортати наративні структури у зв'язну розповідь або історію. Наративна компетентність практичного психолога є вмінням, що дозволяє побачити за історією іншого його індивідуальний наратив.

Мовна форма ставлення до світу виражається у висловлюваннях та їх переплетіннях текстах. Відповідно свідомість людини, що розкриває сенси через тексти, виступає мовним началом. Людина лінгвізує світ та безперервно трансформує його за допомогою власної мови. Проживаючи життя, вона конструює його історію. Ї̈̈ зміст залежить від багатьох умов та чинників, що склалися ще до народження, сформувалися в дитинстві чи зрілому віці.

Згідно з Ф. Джеймсом, усвідомлення досвіду є можливим завдяки оповідній функції, тобто світ є доступним людині лише як історія про неї. Будучи невід'ємною частиною людської реальності, наратив володіє низьким порогом чутливості щодо різноманітних особистісних змін. Структурувальна функція наративу уможливлює впорядкування внутрішньої реальності залежно від змін в усвідомленні й осмисленні досвіду. Ефективність посередницької функції наративу між культурою й особистістю визначається його подвійною природою: наративи є водночас картами світу й особистості, що дозволяє конструювати себе за допомогою історії як частини нашого світу. Осмислення життя відбувається через оповідь як через загальнокультурні та національно-родові наративи, що конструюються на підставі інтеріоризованих культурних взірців. Особистість розглядається оповідачем історії, а отже, у фокусі їі уваги є проблеми «Я».

Н. В. Чепелєва $[14 ; 16]$ пропонує такий підхід до вивчення тексту як моделі взаємодії автора та реципієнта, що передбачає розкриття текстових рамок і вихід у позатекстову реальність: діяльність, у яку він включений, ситуацію, на яку він орієнтований, представленість автора у тексті, роль реципієнта, на якого розрахований текст.

Аналізуючи автонаративи досліджуваних за допомогою запропонованих О. М. Назарук маркерів наративу, виялено, що у студентів I курсу мінімально розвинена здатність до формування наративу (83\% досліджуваних). Лише у $17 \%$ здатність до формування наративу перебуває на стадії розвитку. Здатність до формування наративу в студентів IV курсу виявлена у наступному співвідношенні: 48 \% мають мінімально розвинену здатність до формування наративу, у 25 \% здатність до формування наративу перебуває на стадії розвитку, 27 \% мають сформовану здатність до формування наративу.

Обчислюючи кореляційні зв'язки за допомогою пакету статистичних програм SPSS 11.5, встановлено, що на високому рівні значущості за r-критерієм Спірмена знаходяться: ясність Я-концепції та маркер рівня прояву здатності до продукування наративу $(\mathrm{r}=0,618$; $\mathrm{p}=0,000)$, рефлексивність та маркер рівня прояву здатності до продукування наративу 
$(\mathrm{r}=0,406 ; \mathrm{p}=0,000)$, діалогічна спрямованість у спілкуванні та маркер рівня прояву здатності до продукування наративу $(\mathrm{r}=0,336 ; \mathrm{p}=0,002)$, керування почуттями й емоціями інших та маркер рівня прояву здатності до продукування наративу $(\mathrm{r}=0,334 ; \mathrm{p}=0,002)$, чутливість - раціональність та маркер маркер рівня прояву здатності до продукування наративу $(\mathrm{r}=0,302 ; \mathrm{p}=0,005)$.

Висновки. Отже, «професіоналізм» розглядаємо як результат організаційної і цілеспрямованої професійної діяльності, що передбачає формування особистості, яка має високий рівень професійної компетентності і здатна продуктивно вирішувати соціальні, професійні й особистісні завдання.

Професійна компетентність - це базова характеристика діяльності спеціаліста; вона включає як змістовий (знання), так і процесуальний (уміння) компоненти і має головні суттєві ознаки, а саме: мобільність знань, гнучкість методів професійної діяльності і критичність мислення.

Наративна компетентність є необхідним складником професійної компетентності практичного психолога і засобом усвідомлення ним власного досвіду та власної особистості, що виражається у вмінні побачити за історією особистості, у ході надання психологічної допомоги, іiї індивідуальний наратив.

1. Белолипецкий, В., Павлова, Л. (2004). Этика и культура управления: учебно-практическое пособие. Москва: ИКЦ «Март».

2. Василюк, А. (1998). Польська професійна педагогіка про компетентність вчителя. Шлях освіти. $4,20-23$.

3. Горкуненко, П. (2010). Формування професійної компетентності викладача педагогічного вищого навчального закладу I-II рівнів акредитаиії в контексті загальноєвропейської інтеграції. Взято $з$ http://www.nbuv.gov.ua/portal/Soc_Gum/Npd/2010_1/Gorkunen.pdf

4. Громкова, М. (2003). Психология и педагогика профессиональной деятельности: учеб. пособие для вузов. Москва: ЮНИТИ-ДАНА.

5. Диагностика межличностных отномений подростков и старшеклассников (2003). Калининград: Изд-во КГУ.

6. Исаев, Е. (1997). Психология в высшей школе: проблемы проектирования психологического образования педагога. Вопросы психологии. 6, 48-57.

7. Калина, Н. (1999). Диагностика социального интеллекта личности. Журнал практикующего психолога, 5, 159-178.

8. Кузьмина, Н. (1990). Профессионализм личности преподавателя и мастера производственного обучения: Москва.

9. Маркова, А. (1996). Психология профессионализма. Москва.

10. Методика диагностики уровня развития рефлексивности. Взято из https://psycabi.net/testy/517test-refleksii-metodika-diagnostiki-urovnya-razvitiya-refleksivnosti-oprosnik-karpova-a-v.

11. Методика диагностики эмоиионального интеллекта. Взято из $\mathrm{https} / / \mathrm{hr}$-academy.ru/hrarticle/ metodika- diagnostiki-emotsionalnogo-intellekta.html.

12. Молчанов, С. Профессиональная компетентность и система повышения квалификации педагогических и управленческих работников. Взято из $\mathrm{http} / / / \mathrm{www} .1 \mathrm{ib} . c \mathrm{su} . \mathrm{ru} / \mathrm{vch} / 5 / 2001 \_01 / 008 . \mathrm{pdf}$ /

13. Назарук, О. (2004). Вікові особливості розуміння особистого досвіду (Дис. канд. психол. наук), Ін-т психології ім. Г.С.Костюка АПН України. Київ.

14. Основи психосемантики (за наративними технологіями) (2008). Київ: Главник.

15. Первутинский, В. (2002). Современные подходы к развитию профессиональной компетентности студентов. Санкт-Петербург.

16. Проблеми психологічної герменевтики (2004). Київ: Міленіум.

17. Фетискин, Н., Козлов, В., Мануйлова, Г. (2005). Соииально-психологическая диагностика развития личности и малых групп. Москва: Изд-во Института Психотерапии.

18. Шелянюк, I. (2002). Короткий індекс самоактуалізації та шкала ясності Я-концепції. Практична психологія та соиіальна робота. 6, 26-27.

\section{REFERENCES}

1. Belolypetskiy, V., Pavlova, L. (2004). Etika i kultura upravleniya: uchebno-praktycheskoye posobiye [Ethics and culture of management: practical training material]. Moskva: YKTs «Mart». (rus.).

2. Vasiliuk, A. (1998). Polska profesiina pedahohika pro kompetentnist vchytelia. Shliakh osvity [Polish professional pedagogy about teacher competence], 4, 20-23. (ukr.). 
3. Horkunenko, P. (2010). Formuvannia profesiinoi kompetentnosti vykladacha pedahohichnoho vyshchoho navchalnoho zakladu I-II rivniv akredytatsii v konteksti zahalnoievropeiskoi intehratsii [Formation of professional competence of the teacher of pedagogical higher educational institution of I-II levels of accreditation in the context of pan-European integration]. Retrieved from http://www.nbuv.gov.ua/portal/Soc_ Gum/Npd/ 2010_1/Gorkunen.pdf. (ukr.).

4. Hromkova, M. (2003). Psykholohyia y pedahohyka professyonalnoi deiatelnosty: ucheb. posobye dlia vuzov [Psychology and pedagogy of professional activity: training manual for universities]. Moskva: YuNYTYDANA. (rus.).

5. Diagnostika mezhlichnostnykh otnosheniy podrostkov u starsheklassnikov [Diagnosis of interpersonal relationships of adolescents and High schoolers]. (2003). Kaliningrad: Izd-vo KGU. (rus.).

6. Isayev, E. (1997). Psikhologiya v vysshei shkole: problemy proektyrovaniya psikholohycheskoho obrazovaniya pedagoga. Voprosy psykhologii [Psychology in higher education: problems of designing a teacher's psychological education]. 6, 48-57. (rus.).

7. Kalina, N. (1999) Diagnostika sotsyalnoho intellekta lichnosti. Zhurnal praktikuiushchego psykhologa [Diagnosis of social intelligence of personality]. 5, 159-178. (rus.).

8. Kuzmyna, N. (1990). Professyonalizm lichnosti prepodavatelia i mastera proizvodstvennogo obucheniya [Professionalism of the personality of the teacher and master of vocational training]. Moskva. (rus.).

9. Markova, A. (1996). Psikhologiya professionalizma [Psychology of Professionalism]. Moskva. (rus.).

10. Metodika dyahnostyki urovnia razvitiya refleksivnosti [Method of diagnosing the level of development of reflexivity]. Retrieved from https://psycabi.net/testy/517-test-refleksii-metodika-diagnostiki-urovnya-razvitiyarefleksivnosti-oprosnik-karpova-a-v. (rus.).

11. Metodika dyagnostiki emotsyonalnogo intellekta [Method of diagnosing the level of development of emotional intelligence]. Retrieved from https://hr-academy.ru/hrarticle/metodika-diagnostiki-emotsionalnogointellekta.html. (rus.).

12. Molchanov, S. Professyonalnaia kompetentnost i sistema povysheniya kvalifikatsiyi pedagogicheskikh upravlencheskikh rabotnikov [Professional competence and advanced training system for teachers and managers] Retrieved from http://www.lib.csu.ru/vch/5/2001_01/008.pdf. (rus.).

13. Nazaruk, O. (2004). Vikovi osoblyvosti rozuminnia osobystoho dosvid[Age-specific features of understanding personal experience]. Dys. kand. psykhol. nauk: 19.00.07. In-t psihologiyi im. G.S.Kostyuka APN Ukrayini. Kyiv. (ukr.).

14. Osnovy psykhosemantyky (za naratyvnymy tekhnolohiiamy) [Fundamentals of psychosemantics (based on the narrative technologies]. (2008). Kyiv: Hlavnyk. (ukr.).

15. Pervutsnskiy, V. (2002). Sovremennye podkhody $k$ razvitiyu professionalnoi kompetentnosti studentov [Modern approaches to the development of professional competence of students]. Sankt-Peterburh. (rus.).

16. Problemy psykhologichnoi hermenevtiki [Problems of psychological hermeneutics]. (2004). Kyiv: Milenium. (ukr.).

17. Fetiskin, N., Kozlov, V., Manuilova, H. (2005). Sotsialno-psikholohycheskaia diahnostika razvityia lichnosti y malykh grupp [Socio-psychological diagnosis of the development of personality and small groups]. Moskva. Izd-vo Instituta Psikhoterapii. (rus.).

18. Shelianiuk, I. (2002). Korotkyi indeks samoaktualizatsii ta shkala yasnosti Ya-kontseptsii. Praktychna psykholohiia ta sotsialna robota [Short index of self-actualization and self-concept clarity scale], 6, 26-27. (ukr.).

\section{Tetiana Zdorovets \\ NARRATIVE COMPETENCE AS THE COMPONENT OF PROFESSIONAL COMPETENCE OF FUTURE PRACTICAL PSYCHOLOGISTS}

The paper analyzes the problem of narrative competence of practical psychology as a major component of his professional competence. Professional psychologists competence is shown here as a complex psychological derivation which provides the performance of their professional activities and includes a system of action-role (knowledge, proficiency and skills) and personal (professionally important qualities) characteristics, the most prominent of which is the narrative competence. Narrative competence involves the formation of narrative identity as a structural framework and the presence of "a set of" basic narratives that have a socio-cultural nature, the skills of deploying narrative structure in a coherent narrative or story. The focus of psychological help on work with the needs of customers that are based on the narrative, as the history of the human's life who asked for help makes the study of narrative competence very important, that is realized in the process of understanding and self-reflection and reconsideration of an active subject of information about the world and themselves in it. The narrative competence is revealed as a component of professional competence of a practical psychologist and by means of understanding their own experience and their own personality, which is reflected in the ability to see behind the story of the individual, during providing psychological help her personal narrative. Consistent self-concept, reflexivity, dialogic orientation in communication, management of feelings and emotions of others (the component of emotional intelligence), sensitivity - rationality (the component of communicative competence) is concluded to be 
complementary to the qualities of a practical psychologist, which presence should cause the implementation of personal customer's growth during the individual and group work.

Keywords: narrative competence, narrative, social intelligence, emotional intelligence, dialogism, communicative competence, reflection, consistent self-concept. 